\title{
Fraksi Kloroform Ekstrak Buah Mentimun (Cucumis sativus L.) Sebagai Anti Bakteri terhadap Staphylococcus epidermidis
}

\author{
Pratika Viogenta ${ }^{1}$, Samsuar $^{2}$, Ahmad Ferry Yeriza Utama $^{3}$ \\ ${ }_{1,2,3}$ Jurusan Farmasi, Universitas Tulang Bawang Lampung \\ Email: pratikaviogenta@gmail.com
}

\begin{abstract}
Chloroform Fraction of Extract Cucumber Fruit (Cucumis sativus L.) as of Antibacterial Staphylococcus epidermidis. The use of antibiotics in the community massively trigger resistance to bacteria, to that need for research on other alternatives, especially herbal medicine as an antibacterial. One of the medicinal plants are cucumbers that are widely available in Indonesia. The purpose of this study was to scientifically prove the antibacterial activity of chloroform fraction cucumber extract against Staphylococcus epidermidis. Extraction cucumber done by maceration, then extract fractionated with chloroform. The fraction was used the concentration of $5 \%, 10 \%, 15 \%, 20 \%$ and $25 \%$. Then tested the antibacterial power and determination of the MIC. Results of test antibacterial of the extract chloroform of cucumber against S. epidermidis showed a zone of inhibition at concentrations of 5\%, 10\%, 15\%, 20\%, $25 \%$ diameter respectively $5.86 \mathrm{~mm}, 6.5 \mathrm{~mm}, 7.05 \mathrm{~mm}, 7.43 \mathrm{~mm}$, and $9.92 \mathrm{~mm}$, in addition to it tested the determination of minimum inhibitory concentration, minimum inhibitory concentrations of chloroform fraction extract cucumber fruit against S. epidermidis is at a concentration of $3 \%$. The results obtained from the culture media growth on NA which means the fraction of the chloroform extract of cucumber in $3 \%$ is bacteriostatic.
\end{abstract}

Keywords: Cucumber fruit, Staphylococcus epidermidis, Chloroform

\begin{abstract}
Abstrak: Fraksi Kloroform Ekstrak Buah Mentimun (Cucumis sativus L.) Sebagai Antibakteri terhadap Staphylococcus epidermidis. Penggunaan antibiotik secara besar-besaran di masyarakat memicu terjadinya resistensi terhadap bakteri, Untuk itu perlu adanya penelitian tentang alternatif lain terutama obat herbal sebagai antibakteri. Satu di antara tanaman berkhasiat obat adalah mentimun yang banyak terdapat di Indonesia.Tujuan penelitian ini adalah untuk membuktikan daya antibakteri fraksi kloroform ekstrak buah mentimun terhadap Staphylococcus epidermidis. Ekstraksi buah mentimun dilakukan dengan cara maserasi dengan etanol 70\%, selanjutnya ekstrak difraksinasi dengan kloroform. Fraksi yang digunakan adalah konsentrasi 5\%, $10 \%, 15 \%, 20 \%$, dan $25 \%$. Kemudian dilakukan uji daya antibakteri dan penentuan KHM. Hasil penelitian uji daya antibakteri fraksi kloroform ekstrak buah mentimun terhadap bakteri Staphylococcus epidermidis menunjukan adanya zona hambat pada konsentrasi 5\%, 10\%, 15\%, $20 \%$, 25\% dengan diameter masing-masing $5.86 \mathrm{~mm}, 6.5 \mathrm{~mm}, 7.05 \mathrm{~mm}, 7.43 \mathrm{~mm}$ dan $9.92 \mathrm{~mm}$. Selain itu, konsentrasi hambat minimum fraksi kloroform ekstrak buah mentimun terhadap $S$. epidermidis terdapat pada konsentrasi 3\%. Dari hasil kultur ulang didapatkan pertumbuhan pada media NA yang berarti fraksi kloroform ekstrak buah mentimun pada konsentrasi $3 \%$ bersifat bakteriostatik.
\end{abstract}

Kata kunci: Mentimun, Staphylococcus epidermidis, Kloroform

Tumbuhan merupakan gudang bahan kimia yang memiliki banyak manfaat, termasuk sebagai obat untuk berbagai penyakit. Sejak peradaban manusia itu ada, pemanfaatan tumbuhan sebagai bahan obat sudah dilakukan. Kemampuan meracik obat merupakan warisan turun temurun dan sudah mengakar kuat di masyarakat. Tumbuhan yang merupakan bahan baku obat tradisional tersebut tersebar hampir di seluruh wilayah Indonesia.

Di hutan tropis Indonesia, terdapat 30.000 spesies tumbuhan. Dari jumlah tersebut sekitar 9.600 spesies diketahui berkhasiat sebagai obat
(Prasetyono, 2012). Sejalan dengan perkembangan industri jamu, obat herbal, fitofarmaka, dan kosmetika tradisional, budidaya tanaman obat di Indonesia juga mengalami perkembangan yang signifikan. Penggunaan bahan alam sebagai obat memang mengalami peningkatan. Pada umumnya mereka menganggap tanaman obat lebih alami sehingga lebih aman.

Sari (2006) menyebutkan bahwa, penggunaan obat herbal relatif lebih aman karena efek samping obat herbal yang relatif kecil jika digunakan secara tepat. Penggunaan antibiotik secara besar-besaran di masyarakat memicu terjadinya resistensi terhadap 
bakteri. Penggunaan antibiotika lini pertama yang sudah tidak bermanfaat harus diganti dengan obat-obatan lini kedua atau bahkan lini ketiga. Hal ini jelas akan merugikan pasien, karena antibiotika lini kedua maupun lini ketiga masih sangat mahal harganya. Sayangnya, tidak tertutup kemungkinan juga terjadi kekebalan bakteri terhadap antibiotika lini kedua dan ketiga (Utami, 2011). Untuk itu perlu adanya penelitian tentang alternatif lain terutama obat herbal sebagai antibakteri.

Satu diantara tanaman berkhasiat obat adalah mentimun yang banyak terdapat di Indonesia. Buah mentimun selain dikonsumsi masyarakat juga banyak dimanfaatkan untuk menyembuhkan penyakit salah satunya jerawat (Rukmana, 1995). Pemberian ekstrak mentimun dapat menurunkan tekanan darah sitolik dan diastolik pada penderita hipertensi (Kuntoro, dkk, 2007). Pemberian kombinasi metformin dan ekstrak mentimun juga memberikan efek lebih pada penurunan kadar glukosa pada tikus jantan (Nabila dkk, 2014). Ekstrak mentimun juga memberikan efek anti bakteri terhadap Staphylococcus epidermidis penyebab jerawat (Yusvaneli, 2008).

Bakteri S. epidermidis merupakan bakteri yang menyebabkan pernanahan, infeksi yang terjadi menyebabkan sub akut endokarditis dan penyebab dari infeksi hati dan kardiovaskuler, membran perifer vaskuler, pembuluh intravena dan saluran kemih (Djuanda dkk, 1987).

Kulit merupakan organ terluar tubuh, secara konstan berhubungan dengan bakteri dari udara atau benda-benda lain. Kulit juga mempunyai keragaman yang luas dalam hal struktur dan fungsi di berbagai situs tubuh (Wasitaatmadja, 2007). Satu diantara bakteri yang dapat menyebabkan penyakit pada kulit ialah $S$. epidermidis, bakteri ini termasuk gram positif, aerob dan merupakan flora normal tubuh (Warsa, 1994).

\section{METODE}

Penelitian ini telah dilaksanakan di Laboratorium Farmasi UTB dan Laboratorium Kesehatan Daerah Propinsi Lampung pada bulan Desember 2015 sampai Januari 2016.

Buah mentimun segar sebanyak $5 \mathrm{~kg}$ dikeringkan dan diperoleh sebanyak $165 \mathrm{~g}$ simplisia, kemudian diambil sebanyak $150 \mathrm{~g}$ untuk selanjutnya diekstrak.

Simplisia buah mentimun sebanyak 150 gram dimasukkan ke dalam wadah berwarna gelap dan tambahkan etanol $70 \%$ hingga terendam sempurna, kemudian dimaserasi hingga terekstrak sempurna dan diperoleh ekstrak buah mentimun dalam etanol dan ampas. Ekstrak diuapkan menggunakan destilasi vacum sampai 150ml. Ekstrak kemudian diasamkan dengan menambahkan $\mathrm{H}_{2} \mathrm{SO}_{4} 2 \mathrm{~N}$ hingga $\mathrm{pH}$ 3-5 kemudian ditambahkan $\mathrm{CHCl}_{3}$ dengan perbandingan 1:1 dalam corong pisah. Perlakuan ini dilakukan 3 kali pengulangan atau hingga tidak terjadi perubahan warna pada $\mathrm{CHCl}_{3}$, setelah diperoleh ekstrak buah mentimun dalam $\mathrm{CHCl}_{3}$ dan lapisan air-asam, ekstrak buah mentimun dalam $\mathrm{CHCl}_{3}$ lalu diuapkan dengan destilasi vakum hingga seluruh kloroform menguap dan larutkan dengan aquadest hingga 150 $\mathrm{ml}$.

Persiapan bakteri uji untuk uji daya antibakteri menggunakan metode sebar. Cawan petri steril disiapkan kemudian ditambahkan media NA sebanyak $20 \mathrm{ml}$, setelah media memadat sebarkan suspensi $S$. epidermidis yang telah dibuat dengan menggunakan kapas (cotton bud) yang telah disterilkan hingga merata keseluruh permukaan media. Kertas cakram langsung dicelupkan ke dalam fraksi kloroform ekstrak buah mentimun dengan konsentrasi 5\%, $10 \%, 15 \%, 20 \%$, dan $25 \%$, aquades sebagai kontrol negatif, dan eritromisin sebagai kontrol positif, dilakukan sebanyak 5 kali pengulangan. Kemudian diletakkan ke permukaan lempeng agar yang telah ditanami bakteri. Inkubasi selama 24 jam pada suhu $37^{\circ} \mathrm{C}$ dan amati serta ukur diameter zona hambat yang terbentuk. Pengukuran zona hambat yaitu dengan membalikan cawan petri sehingga terlihat daerah hambatan yang tampak transparan, kemudian dengan jangka sorong daerah inhibisi diukur diameternya dan dicatat (Pratiwi, 2008). Setelah didapat konsentrasi terkecil yang memberikan zona hambat dilanjutkan dengan penentuan Konsentrasi Hambat Minimum (KHM).

Untuk pengujian daya hambat minimum menggunakan metode dilusi. Beberapa tabung reaksi yang berisi NB ditambah dengan variasi dosis dari konsentrasi terkecil yang didapat dari uji daya antibakteri sampai dosis yang tidak memberikan daya hambat yaitu 1\%, 2\%, 3\%, 4\% dan $5 \%$ serta ditambah $0,1 \mathrm{ml}$ suspensi bakteri $S$. epidermidis. Masing-masing tabung diinkubasi selama 24 jam. Pengamatan dilakukan dengan membandingkan kekeruhan media. Larutan uji dengan agen antimikroba pada kadar terkecil yang terlihat jernih tanpa adanya pertumbuhan mikroba ditetapkan sebagai konsentrasi hambat minimun. Larutan yang ditetapkan sebagai KHM tersebut selanjutnya dibiakan ulang pada media NA dan diinkubasi selama 18-24 jam untuk menentukan larutan bersifat bakteriostatik atau bakterisid. 


\section{HASIL}

Sebanyak 150 gram simplisia buah mentimun diekstrak dengan menggunakan metode maserasi dengan pelarut etanol $70 \%$. Hasil maserasi didapatkan maserat sebanyak 3 liter, kemudian dilakukan pemisahan antara pelarut dengan ekstrak menggunakan destilasi vakum hinggal $150 \mathrm{ml}$. Ekstrak cair selanjutnya difraksinasi sehingga diperoleh $500 \mathrm{~mL}$ fraksi kloroform, pemekatan fraksi kloroform dilakukan dengan destilasi vakum hingga kloroform teruap sempurna kemudian ekstrak diencerkan dengan aquadest hingga $150 \mathrm{ml}$.

Hasil penelitian uji daya antibakteri fraksi kloroform ekstrak buah mentimun terhadap bakteri $S$. epidermidis menunjukan adanya zona hambat ada konsentrasi 5\%, 10\%, 15\%, 20\%, 25\% (Tabel 1 dan Gambar 1).

Tabel 1. Hasil Rata-Rata Pengukuran Zona Hambat Fraksi Kloroform Ekstrak Buah Mentimun Terhadap Bakteri $S$. epidermidis

\begin{tabular}{cr}
\hline $\begin{array}{c}\text { Perlakuan } \\
\text { (Konsentrasi) }\end{array}$ & $\begin{array}{r}\text { Rata-rata zona } \\
\text { hambat }(\mathbf{m m})\end{array}$ \\
\hline P1 & $0^{\mathrm{g}}$ \\
\hline P2 & $26,92^{\mathrm{a}}$ \\
\hline P3 & $5,86^{\mathrm{f}}$ \\
\hline P4 & $6,5^{\mathrm{e}}$ \\
\hline P5 & $7,05^{\mathrm{d}}$ \\
\hline P6 & $7,43^{\mathrm{c}}$ \\
\hline P7 & $9,92^{\mathrm{b}}$ \\
\hline
\end{tabular}

Keterangan :

P1 : Kontrol negatif (Aquadest)

P2 : Kontrol positif (Eritromisin)

P3 : Konsentrasi 5\%

P4 : Konsentrasi $10 \%$

P5 : Konsentrasi $15 \%$

P6 : Konsentrasi 20\%

P7 : Konsentasi 25\%

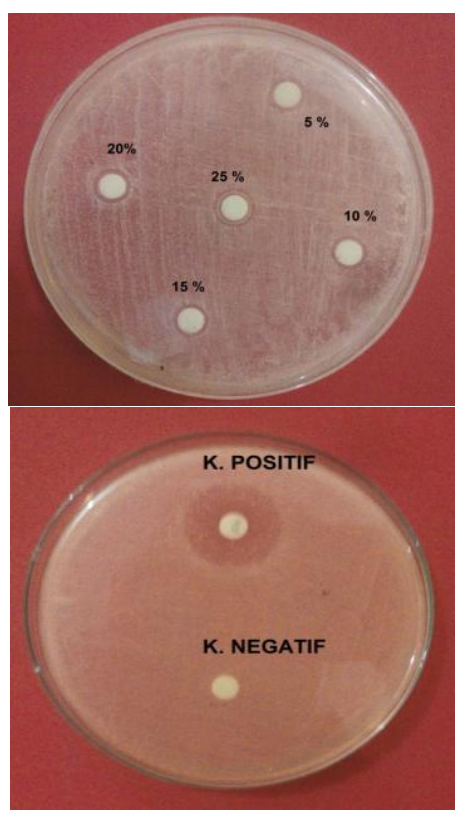

Gambar 1. Hasil Uji Daya Antibakteri terhadap S. epidermidis

Konsentrasi terkecil fraksi ekstrak buah mentimun yang menghasilkan zona hambat yaitu $5 \%$ kemudian diperkecil lagi dari $1 \%$ hingga $4 \%$ dan diujikan kembali dengan $S$. epidermidis untuk mengetahui konsentrasi hambat minimum fraksi ekstrak buah mentimun (Gambar 2).

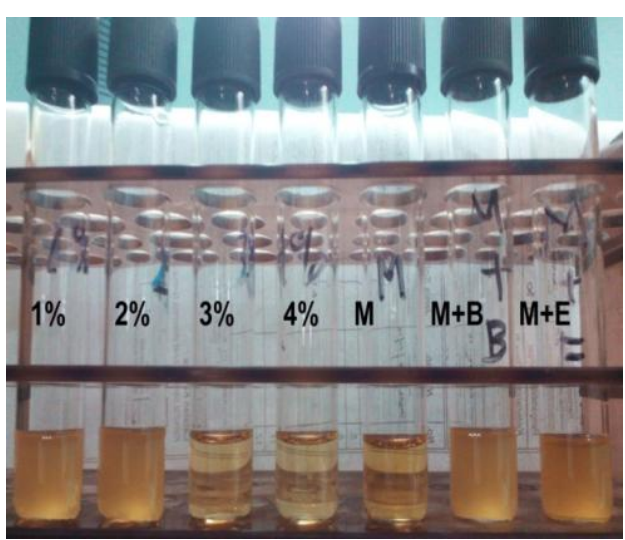

\section{Gambar 2. Hasil Penentuan KHM Fraksi Kloroform Ekstrak Buah Mentimun terhadap $S$. epidermidis}

Hasil pertumbuhan dari uji KHM yang tidak menunjukkan kekeruhan bakteri ditumbuhkan di media padat untuk mengetahui sifat fraksi kloroform ektrak buah mentimun menghambat atau membunuh $S$. epidermidis (Gambar 3). 


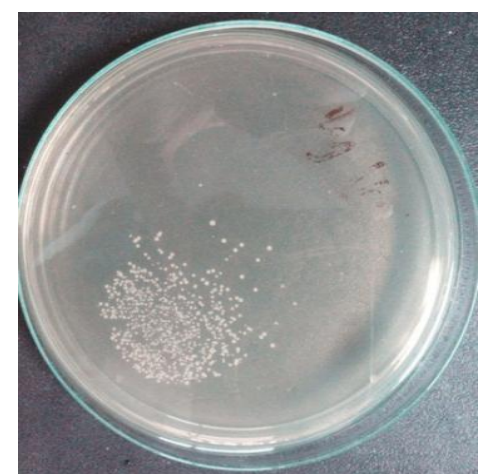

\section{Gambar 3. Pertumbuhan Bakteri pada Kultur Ulang}

\section{PEMBAHASAN}

Bahan baku buah mentimun yang digunakan hasil dari proses pengeringan di bawah matahari sehingga diperoleh simplisia buah mentimun. Pembuatan simplisia dimaksudkan agar bahan dapat disimpan dalam jangka waktu yang lama dengan mengurangi kadar air.

Simplisia buah mentimun diekstrak dengan menggunakan metode maserasi yaitu metode ekstraksi dingin dengan cara perendaman, metode ini memiliki beberapa kelebihan yaitu alat yang digunakan relatif sederhana, biaya relatif rendah dan proses penyarian yang tergolong hemat. Buah mentimun yang telah dikeringkan dimaserasi selama 3 hari. Berakhirnya maserasi ditandai dengan perubahan warna pada simplisia dan pelarut. Warna simplisia menjadi lebih pucat dan warna pelarut menjadi bening (tidak berubah warna). Pelarut yang digunakan untuk maserasi dapat berupa air, methanol maupun etanol. Pada penelitian ini pelarut yang digunakan adalah etanol $70 \%$ dikarenakan pelarut ini relatif lebih aman dibandingkan methanol dan memiliki kelebihan dibandingkan air yang rentan terjadi pertumbuhan kapang dan jamur pada saat perendaman (Depkes RI, 1986). Pemilihan etanol $70 \%$ dikarenakan memliki kadar air yang lebih banyak dibandingkan dengan etanol $96 \%$ sehingga diharapkan dapat membuka sel simplisa yang mengecil pada proses pengeringan sehingga etanol dapat mengikat zat aktif yang ada di simplisia, dari hasil maserasi didapatkan maserat sebanyak 3 liter, kemudian dilakukan pemisahan antara pelarut dengan ekstrak menggunakan destilasi vakum, tujuan penggunaan destilasi vakum adalah untuk mencegah kerusakan zat aktif dalam simplisa karena pemanasan tinggi, kemudian maserat dipekatkan hingga $150 \mathrm{ml}$.

Daya antibakteri yang dihasilkan pada fraksi kloroform ekstrak buah mentimun dapat diamati dari terbentuknya zona hambat disekitar kertas cakram.Ini terbukti pada konsentrasi $25 \%$, $20 \%, 15 \%, 10 \%, 5 \%$ memiliki daya hambat. Hal ini menunjukan bahwa fraksi kloroform ekstrak buah mentimun mampu menghambat pertumbuhan bakteri S. epidermidis. Berdasarkan penelitian ini terbukti bahwa fraksi kloroform ekstrak buah mentimun mampu menghambat pertumbuhan bakteri $S$. epidermidis dengan terbentuknya zona hambat disekitar kertas cakram.

Penghambatan pertumbuhan bakteri $S$. epidermidis oleh fraksi kloroform ekstrak buah mentimun dimungkinkan karena adanya zat aktif yang terdapat pada larutan uji yang berefek sebagai antibakteri. Timun mengandung beberapa senyawa aktif sebagai antibakteri diantaranya, saponin, polifenol dan terpenoid. Saponin yang terdapat pada buah mentimun termasuk dalam kelompok antibakteri yang menggangu permeabilitas membran sel mikroba, yang mengakibatkan kerusakan membran sel dan menyebabkan keluarnya berbagai komponen penting dari dalam mikroba yaitu protein, asam nukleat, nukleotida dan lain-lain. Mekanisme terpenoid sebagai antibakteri adalah bereaksi dengan porin (protein transmembran) pada membran luar dinding sel bakteri, membentuk ikatan polimer yang kuat sehingga mengakibatkan rusaknya porin. Rusaknya porin yang merupakan pintu keluar masuknya senyawa akan mengurangi permeabilitas dinding sel bakteri yang akan mengakibatkan sel bakteri akan kekurangan nutrisi, sehingga pertumbuhan bakteri terhambat atau mati (Ganiswara, 1995). Polifenol merupakan turunan fenol yang mekanisme kerjanya sebagai antibakteri dengan cara mendenaturasi dan koagulasi protein (Cowan, 1999). Sebagai kontrol positif mekanisme kerja eritromisin adalah dengan menghambat sintesis protein dan sangat baik untuk bakteri coccus gram positif (Pratiwi, 2008).

Secara umum, terlihat adanya penurunan zona hambat yang terbentuk pada konsentrasi $(25 \%, 20,15 \%, 10 \%, 5 \%)$ hal ini dapat disebabkan karena pengaruh faktor konsentrasi larutan uji. Semakin tinggi konsentrasi larutan uji semakin meningkat daya antibakteri atau semakin besar zona hambatnya.

Nilai rerata dari zona hambat pada konsentrasi $25 \%$ lebih besar dibandingkan dengan konsentrasi lain sehingga dapat dinyatakan bahwa konsentrasi 25\% yang lebih efektif. Hal ini didukung dengan perbedaan range diameter zona hambat kontrol positif dengan konsentrasi $25 \%$ sebesar $17 \mathrm{~mm}$ dibandingkan dengan konsentrasi lain. Namun dengan perbandingan yang signifikan antara kontrol 
positif dan konsentrasi uji menandakan bahwa hasil belum bisa mendekati kontrol positif tetapi hanya memiliki efek. Hal ini mungkin dikarenakan konsentrasi yang dipakai pada pengujian ini relatif kecil. Eritromisin merupakan antibiotik golongan makrolida yaitu antibiotik yang memiliki cincin makrosiklik. Mekanisme kerja eritromisin sebagai antimikroba adalah dengan menghambat sintesis protein bakteri, dengan menyekat reaksi translokasi asil amino dalam ribosom, dengan pengikatan ribosom bakteri yang kekuatannya bergantung pada struktur antibiotik dan RNA ribosom bakteri (Pratiwi, 2008).

Penentuan konsentrasi hambat minimum fraksi kloroform ekstrak buah mentimun terhadap $S$. epidermidis yang dilakukan dengan menurunkan konsentrasi $4 \%$ sampai $1 \%$ memperlihatkan adanya daya hambat dari konsentrasi $4 \%$ sampai dengan konsentrasi 3\% dan pada konsentrasi $2 \%$ dan $1 \%$ tidak memperlihatkan adanya daya hambat.

Dari hasil penentuan konsentrasi hambat minimun didapat hasil terkecil adalah sebesar 3\%, hal ini dilihat dari tidak terdapat pertumbuhan bakteri pada konsentrasi tersebut, maka konsentrasi 3\% dinyatakan sebagai konsentrasi hambat minimum. Selanjutnya dilakukan biakan ulang pada media NA. Hasil biakan ulang didapat pertumbuhan bakteri pada media, sehingga fraksi kloroform ekstrak buah mentimun dengan konsentarsi $3 \%$ hanya menghambat pertumbuhan S.epidermidis (Bakteriostatik).

\section{SIMPULAN}

Berdasarkan hasil penelitian yang telah dilakukan dapat disimpulkan bahwa fraksi kloroform ekstrak buah mentimun terbukti memiliki daya antibakteri terhadap bakteri $S$. epidermidis secara in vitro.

Pada penelitian ini konsentrasi hambat minimum dari fraksi kloroform ekstrak buah mentimun adalah sebesar 3\%.

\section{SARAN}

Sehubungan dengan penelitian fraksi kloroform ekstrak buah mentimun terhadap pertumbuhan S. epidermidis yang telah dilakukan maka disarankan pada penelitian selanjutnya untuk meningkatkan konsterasi fraksi kloroform ekstrak buah mentimun sehingga bisa memiliki daya bunuh dan kedepannya dapat diaplikasikan dalam pembuatan kosmetik.

\section{DAFTAR PUSTAKA}

Cowan MM. 1999. Plant Products as Antimicrobial Agents. Clin Microbiol Rev. 12(4):564-582.

Djuanda A. 2015. Ilmu Penyakit dan Kelamin. VII. Jakarta: Universitas Indonesia.

Ganiswara S. 1995. Farmakologi dan Terapi. Jakarta: Gaya Baru.

Kuntoro, K., Wirjatmadi, B., \& Muniroh, L. 2007. Pengaruh Pemberian Jus Buah Belimbing dan Mentimun terhadap Penurunan Tekanan Darah Sistolik dan Diastolik Penderita Hipertensi. Indonesian Journal of Public Health, 4(1).

Nabila, Sugiyanta, Kristianingrum D. 2014. Pengaruh Terapi Kombinasi Ekstrak Etanol Mentimun (Cucumis sativus) dan Metformin Terhadap Penurunan Kadar Glukosa Darah Tikus Wistar yang Diinduksi Aloksan. Jember: Universitas Jember.

Pratiwi ST. 2008. Mikrobiologi Farmasi. Jakarta:

\section{Erlangga.}

Prasetyono DS. 2012. Tanaman Obat Ampuh. Jakarta: Flashbook.

Rukmana R. 1995. Budidaya Mentimun. Jakarta: Kanisius.

Sari LO. 2006. Pemanfaatan Obat Tradisional dengan Pertimbangan Menfaaat dan Keamanannya. Majalah Ilmu Kefarmasian. 3(1): 01-07.

Utami ER. 2011. Resisten Antibiotikansi dan Rasionalitas Terapi. El-Hayah. 1(4) : 191.

Warsa UC. 1994. Mikrobiologi Kedokteran. Jakarta: Binarupa Aksara.

Wasitaatmadja MS. 2007. Ilmu Penyakit Kulit dan Kelamin. Edisi V. Jakarta: Universitas Indonesia.

Yusvaneli. 2008. Uji Aktifitas Antibakteri Ekstrak Buah Mentimun terhadap Staphylococcus epidermidis. Bandar Lampung: Universitas Tulang Bawang. 